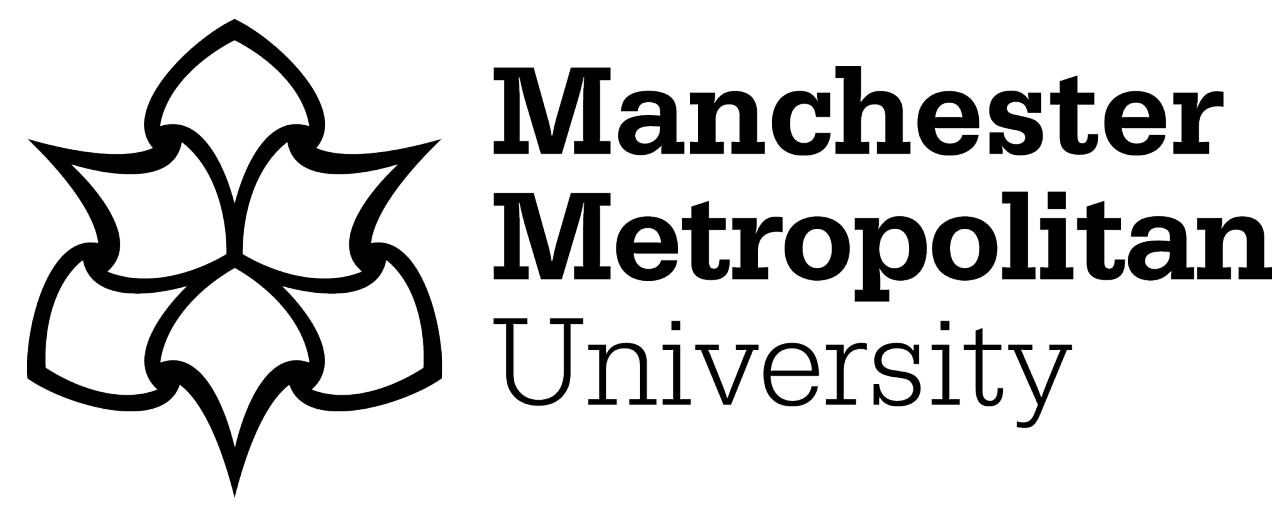

McKnight, L, Rousell, D, Charteris, J, Thomas, K and Burke, G (2017) The invisible hand: designing curriculum in the afterward. International Journal of Qualitative Studies in Education, 30 (7). pp. 635-655. ISSN 0951-8398

Downloaded from: https://e-space.mmu.ac.uk/618358/

Version: Accepted Version

Publisher: Taylor \& Francis

DOI: https://doi.org/10.1080/09518398.2017.1286406

Please cite the published version 


\section{The invisible hand: Designing curriculum in the afterward}

Lucinda McKnight (corresponding author)

School of Education, Deakin University, Melbourne, Australia

221 Burwood Highway

Burwood 3125 Australia

l.mcknight@ deakin.edu.au

David Rousell

School of Education, Southern Cross University, Lismore, Australia david.rousell@scu.edu.au

Jennifer Charteris

School of Education, University of New England, Armidale, Australia jcharte5@une.edu.au

Kat Thomas

School of Humanities, University of Auckland, Auckland, New Zealand k.thomas@auckland.ac.nz

Geraldine Burke

School of Early Childhood and Primary Education, Monash University, Melbourne, Australia

geraldine.burke@monash.edu 
Biographical Notes

Lucinda McKnight is a lecturer in the school of Education at Deakin University. She has a BA in Fine Arts, an MA in Media, Culture and Communication, and a $\mathrm{PhD}$ in Education. Her research interests are in the transdisciplinary studies of curriculum design and creative research methodologies. She is also a qualified teacher of Creative Writing and award-winning writer and playwright.

David Rousell is a doctoral candidate in the School of Education at Southern Cross University. David's transdisciplinary doctoral project collectively re-imagines university learning environments in response to the changing social and ecological conditions of the Anthropocene. David is also Research Fellow in the School of Education, working on the threeyear Climate Change and Me project with children and young people as co-researchers.

Jennifer Charteris is a teacher educator with over 21 years of teaching experience in New Zealand, Australia and the UK, working with students, teachers, principals, school communities and school in-service advisors. She has taught in the primary, secondary and tertiary sectors. Jennifer has a doctorate in Education and lectures in research methods and learning theories at the University of New England, Armidale, Australia.

Kat Thomas is a $\mathrm{PhD}$ candidate at the University of Auckland under the supervision of Professor Peter O'Connor and Dr Molly Mullen. Kat completed a BA (Hons) in English and Theatre Studies at Otago University, and a Master of Theatre Arts in directing taught jointly between Toi Whakaari: NZ Drama School and Victoria University of Wellington. She is interested in the artist and academic collision in terms of making, creating and considering applied theatre as a tool for intimate social revolutions.

Geraldine is an artist, researcher, teacher-educator lecturing into studio and creative arts education at Monash University (Melbourne and Singapore). She has an enduring interest in how local knowledge/s, place and immersive a/r/t (art, research, teaching) develop across community groups. She has an MA in Art and Design (exhibition/ exegesis) and a $\mathrm{PhD}$ (photo-book/exegesis) that explored immersive art pedagogy. 


\section{The invisible hand: Designing curriculum in the afterward}

This paper diffracts a curriculum design workshop via online collaboration of a collective emerging from that event. Through the workshop, involving theory, conceptual art, writing, photography and curriculum planning, and the subsequent sharing of words and images, we move beyond interrogating designs for future subjects to asking how the pedagogical imagination composes both the material and immaterial, the corporeal and incorporeal, within ecologies continually transforming in the process of making. We complicate 'delivery' or 'conduit' metaphors of education and perceive 'design' in co-compositions of human and nonhuman elements, resisting stasis, resisting closure. This workshop-paper positions design in the realm of the artist-activist, rather than that of the bureaucrattechnician, and shifts intentionality beyond the invisible and controlling hand of humanism, as curriculum design we might do in the afterward, rejecting instrumentalism.

Keywords: curriculum design; pedagogy; new materialism; posthumanism; post qualitative research

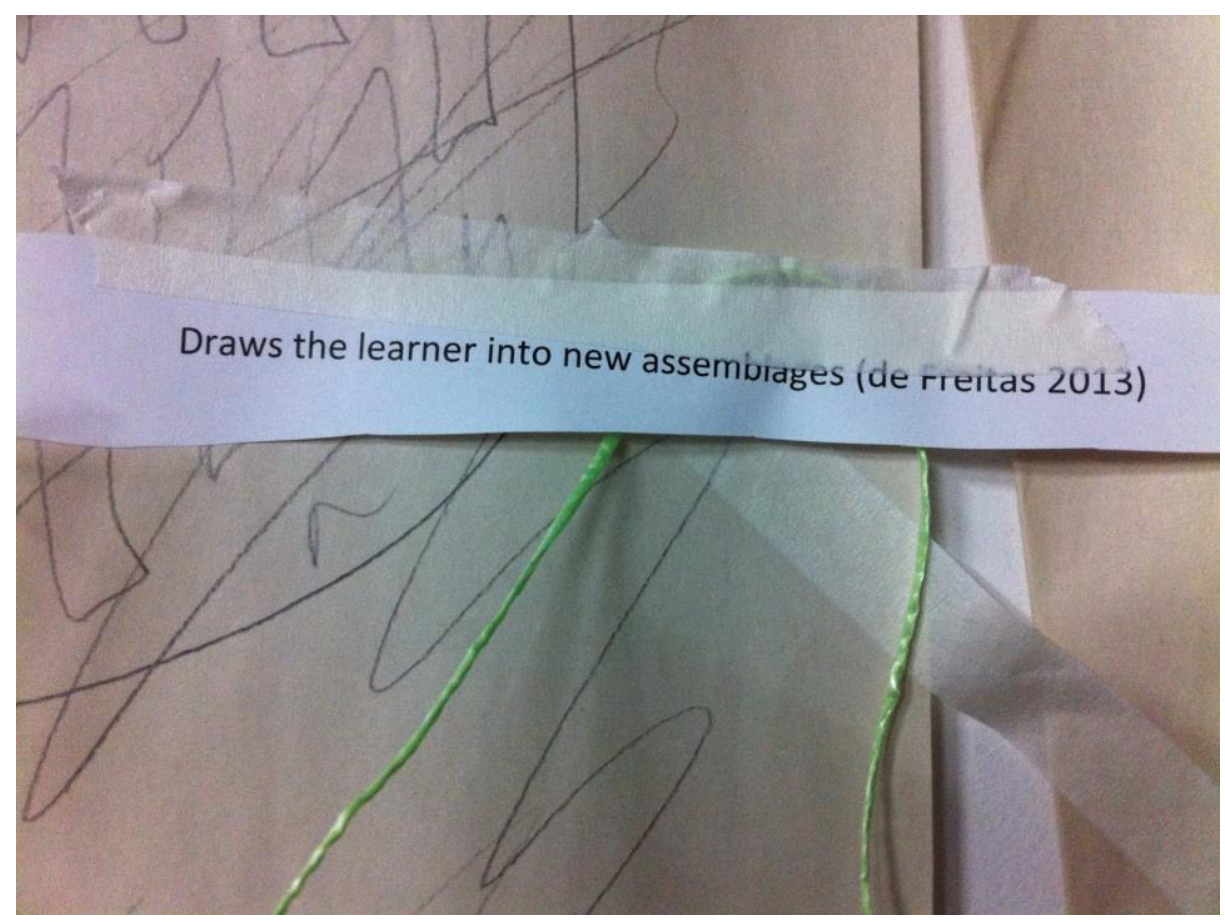

Figure 1: The Invisible Hand conference workshop assemblage detail 


\section{Introduction}

In September 2015 the Art Auditorium at the Victorian College of the Arts hosted a curriculum design workshop within the Transversal Practices: Matter, Ecology and Relationality VI Conference on New Materialism program. Flowing out of that event, a collaborative assemblage began to emerge, composed from memories, ideas and further encounters; this is an assemblage in the sense of Karen Barad's entanglement of agencies (2007), of pixels, photographs, words and avatars. Our human participants are writerartist-lecturer-physiotherapist-dramatist-researcher-teacher educator-student, performing the cut across disciplines that is key to new materialist transversalism (van der Tuin \& Dolphijn, 2010, p. 159).

As a collective, we feel that the published conference paper that ignores the performative nature of its 'delivery', and its spatial, material and temporal potentials, is a particular kind of humanist fiction. We are intrigued by how we might compose curriculum transversally with matter (recognising the spontaneous materiality of pedagogical practices), with ecology (offering this article as partial, thinly-bound work of ever-transforming systems) and with relationality, as we move in and with. These are the mobile orientations we bring to curriculum design, forming both methodologies-tocome (Lather, 2013, p. 635) and curriculum-to-be. As Patti Lather advises, we are alert to multi-directionalities, to intra-actional networks and to the messy incompleteness (2013, p. 641) of any educational event. This is curriculum in Lather's afterward, forming in temporalities beyond the conventional.

In this paper, we re-make the experience of the workshop and also what unfolds beyond its purported boundaries as our collective intra-acts to call new entities into being (Barad, 2007). These intra-actions iteratively produce the material-discursive phenomena 
of collaboration and curriculum; through intra-action we transversally and mutually constitute the diverse entities called into play (van der Tuin \& Dolphijn, 2010, p. 168) and complicate the dualism of presenter/participants. In this paper we aim to think and work transversalism as a pragmatics which operates across institutional domains of school, university and conference curricula, the deterritorialised movements of thought after humanism, and the possibility spaces created by non-discursive creative production. In doing so, we acknowledge transversality as a conceptual practice that is able to 'bridge' divergent ontological postitionings and stratifications through a 'social and political experimentality' that is oriented towards the production of new collective assemblages and subjectivities (Genosko, 2008, p. 74).

The conference workshop set this up by commencing without a presenter, flattening the teacher figure into the landscape of the auditorium, remaining open to transformation; the 'stage' merely contained an envelope, lamp-lit on a plastic chair, for participants to open if they wished (McKnight, 2015), thus disrupting the customary teacher-presenter introduction. For participants, this enabled the removal of conference 'cloaks of passivity' and the emergence of self-shadows negotiating and navigating collaboration, elated at encountering the unexpected. An invisible hand set up the workshop, and further invisible hands conjure the magic of type in our machine-enabled, co-written paper, synecdochical reminders of an increasingly tenuous humanist history that these hands, and other collaborators, conspire to undermine.

Our chief contribution in this paper is to perform how the transversalism of assemblage and intra-action might be put to work in relation to curriculum in the afterward. Instead of producing a neat lesson plan in an apparently unified voice with predetermined lists of assumed outcomes or a conference paper delivering finalised research findings, we invite readers to entertain what curriculum might be/come and share 
processes of making emerging in and from the rogue practices of the workshop. This assemblage is also created by the images included, which are the materially realised elements of the larger artwork created at the conference, now souvenired and forming parts of subsequent assemblages in other spaces. These images acknowledge and draw in the matter involved in practice, challenging the usual pretence that a conference presentation occurs in a purely cognitive and discursive domain; they throw us out of the text and back to the embodied materiality of the workshop (Mazzei, 2013), to the place where we will always and never again be. Hence, in our experimentation with transversal approaches to producing research as a collective process of creation, we also aim to contribute to the proliferation of new formats and modalities for research publication, dissemination and engagement with the wider public (see, for example, Rhoades \& Brunner, 2010; Otterstad \& Waterhouse, 2015; Cutcher, Rousell \& Cutter-Mackenzie, 2015).

In the first section of the paper we describe the workshop, and include the two pieces of writing read aloud as it unfolded, then in the second section, we propose transversal curricular forms and practices. These are diverse figurations emerging online as we write, edit and insert photographs; figurations that multiply, again and again, as our reader and text intra-act. In the final section, we reinstate and dissolve the absent teacher, owner of the invisible hand that wrote the conference abstract, succumbing to the lure of the humanist story, and illustrating how it forms just part of a larger assemblage- we position ourselves as post-humanist, not anti-humanist (Coole \& Frost, 2010, p.8). 


\section{Part I: The invisible hand workshop}

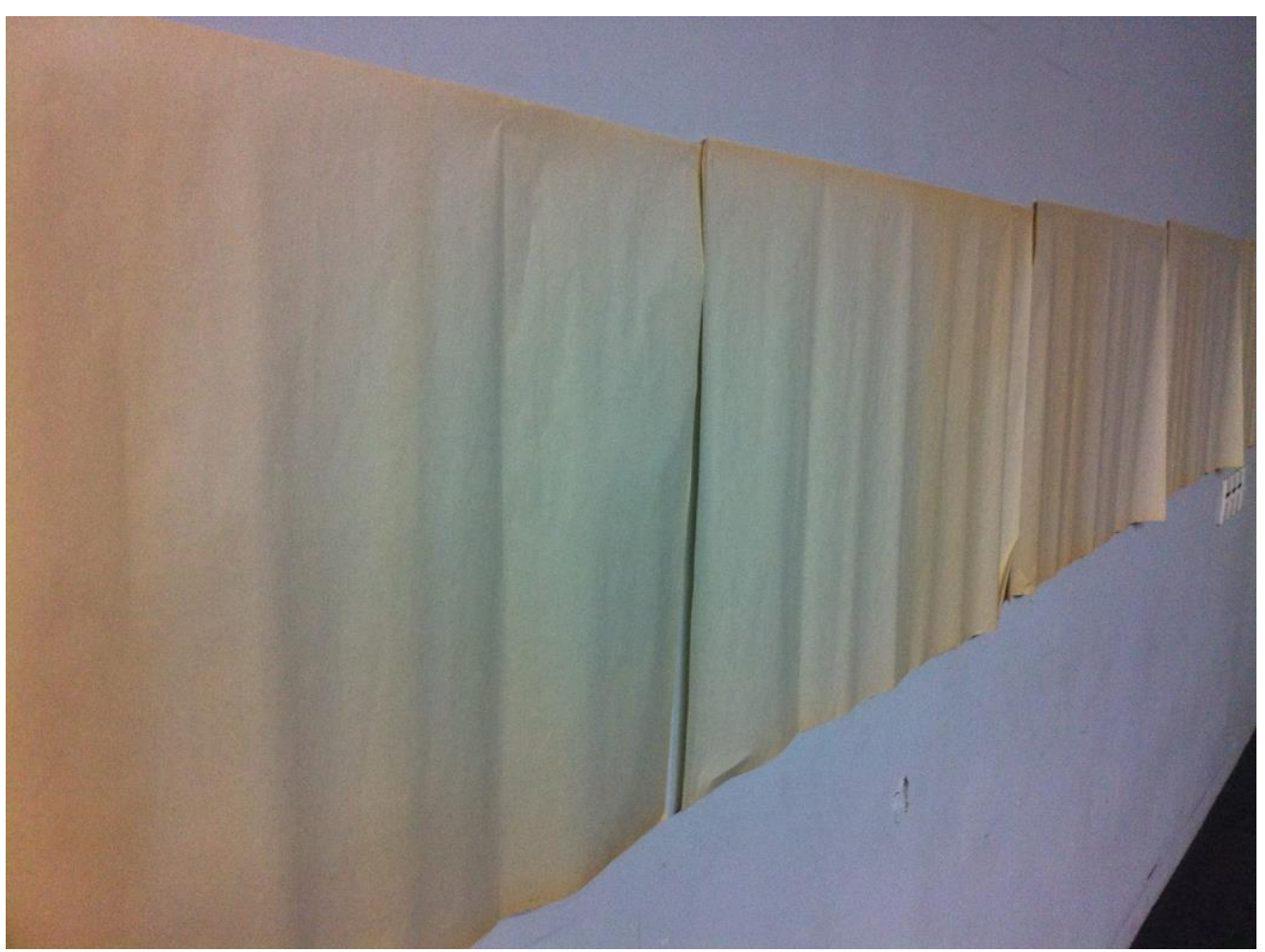

Figure 2: Walls ready for The Invisible Hand Workshop

A conference. A room. Paper around the walls. No presenter. A chair. An envelope labelled 'Open me when it feels necessary'. Discussion. A rustle. An unfolding. Words on a page. An instruction: 'Please read aloud'. A volunteer participant's voice reads:

So here we are. What are we expecting? A presenter? A PowerPoint? A plan? Outcomes? Handouts? A reference list? We have none of these. Instead we have plastic-paint-fluorofingers-envelope-paper-tree-glue-breath. How do we feel about this? Uncomfortable? Excited? Exasperated? How much have we invested in comfortable binaries of: presenter/participant; 
teacher/student;

policy/strategy;

theory/practice;

knowledge/knower;

plan/action.

New materialism has proposed 'the end... of curriculum' (Gaztambide-Fernandez, 2015, p. 248). Nathan Snaza (2015) predicts teachers will cease to plan, but we are not there yet. We are still facing someone, sedimented here by our chairs, waiting for someone, Descartes, maybe, to stand up and claim the invisible hand orchestrating this. How can we 'do' curriculum design when cause, effect, intentionality, sequencing and linearity are problematic (Barad, 2003)? How can we think curriculum design when matter suddenly has vibrancy (Bennett, 2010, p. xiii), when we become aware that the most lasting change on/in us, after this workshop, might come from the pedagogy of the chair, which is shortening our hip flexors, slackening our hamstrings, flattening the lordosis of our spines, teaching our bodies how to be.

Is this a gimmick? It is hard to de-centre the 'I', to deny the journey metaphor, to refuse the tour guide, the expert explorer who has been there first, who exists before the journey and after, before the plan and after. We are so finely trained in humanism, in being massaged towards becoming a better person, teacher, human. We are hungry for the methodology, the model that might co-opt new materialism to this great project. We can hardly tear ourselves from the 'lens', the 'reading', the 'frame', the distancing that splices us and 'data'. We are deeply attached to the work of imagining the future human subjects our curriculum planning might bring forth.

There is no model today. All we can do is wriggle, make a small movement as a moth shifts in a cocoon. And there are a thousand ways to wriggle, like Patti Lather's 
thousand methodologies (2013). There may be no new materialist way to do curriculum design. We could forget those words. We could instead see this workshop as an event, an assemblage-intra-action-entanglement-mangle, in which many entities, through acting on each other, come into being, and evolve something that used to be thought of as a plan. A proposition. A possibility. A chimera. A co-creation. Something that resists being handed over and understood, and yet in becoming, in altering itself, might alter other intra-actions yet to come.

So what happens next? Let's get up, greet each other, press flesh, remember we are (partly) flesh, shake hands, introduce ourselves and look at each other, not at the expert out the front, move the chairs into a circle, feel their density resist us but persevere. Then we can have a kind of beginning that doesn't happen at the start.

The reading finishes. Standing. Hands. Skin. Smiles. Names. Reveal.

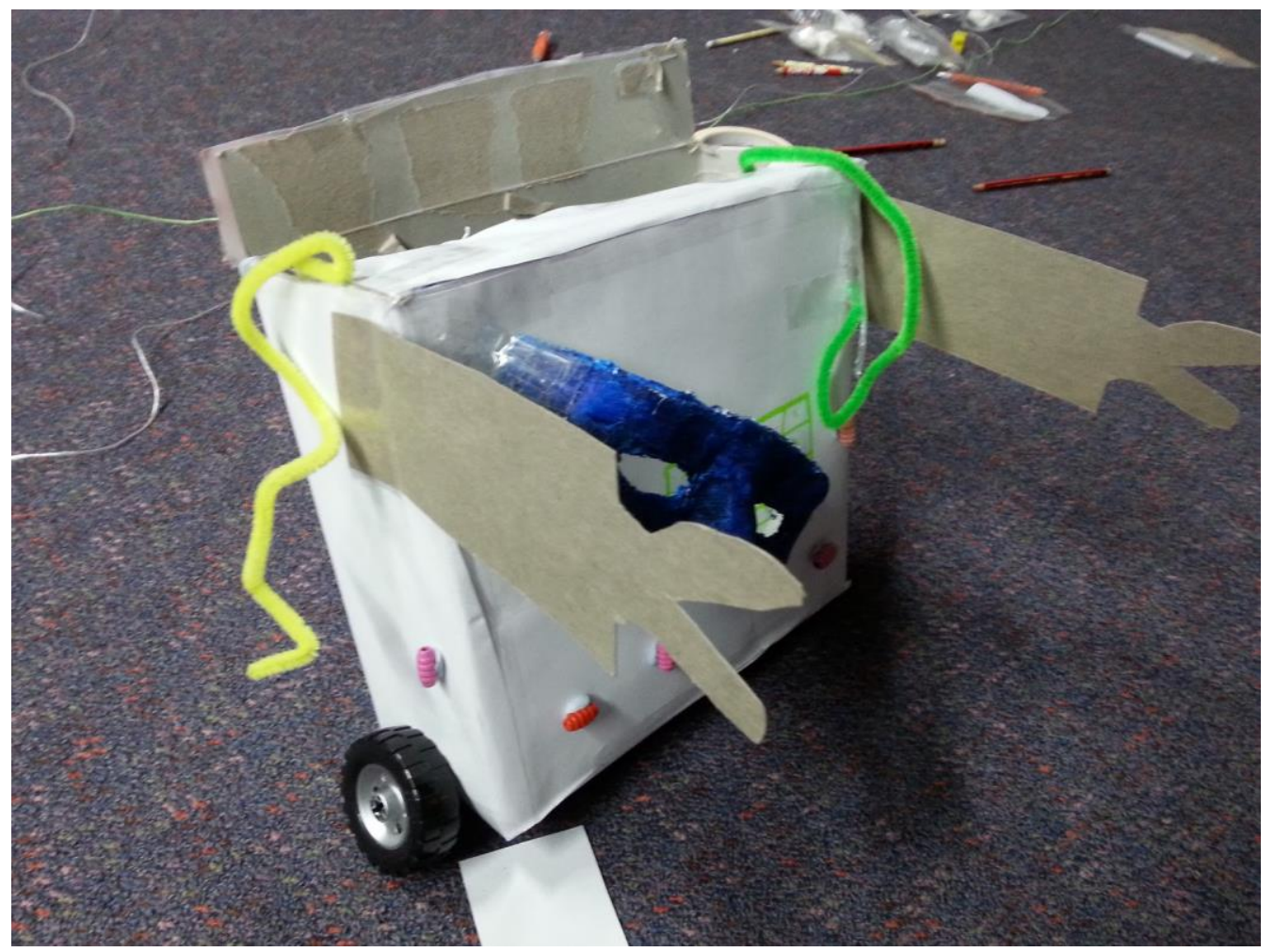

Figure 3: Cardboard box mangle displayed at workshop, made by presenter's son 
'So you're the presenter!'

Thank goodness. The presenter emerges. Relief in recognition? Muscles relax. We have a physical scaffolding, an organism that persons (Arakawa \& Gins, 2002, p. 1).

Chairs again. Words. Wind. Debate. Paper lifts and settles on the walls. Another reading. The 'presenter' this time:

Curriculum documents are usually seen as mirrors of our intentions, or more poststructurally and reflexively, as failed representations of discursive attempts to interpellate subjects. Intentions are a Cartesian "habit of mind", a by product of the binary division of inside and outside, where we can have sovereign knowledge of our world and impose a knowable structure on it (Barad, 2003, p. 807). In short, intentions are a "Cartesian cut" that fosters arbitrary distinctions between subject and object (p. 815. What if, instead of reflecting, we diffract intentions with art, with poetry, drawing, making, writing fiction, performing, moving? What if we do this, instead of writing outcomes and descriptors? Pre-service teachers in many schools must write their lesson steps and outcomes on the board before they start a lesson, and they are assessed on whether they deviate. Nathan Snaza (2015) sees the result of a decade of this kind of teaching and learning as passivity. Our students say 'just tell us what to do'.

What if our propositions are understood to be ephemeral, contingent and themselves emerging in ways beyond our control, much more than themselves, not frames, but in the mix, various tracings on a map of possibilities (Deleuze \& Guattari, 1987)? We might propose something here, an assemblage proposition for further assemblages, an experiment event, awake to the tensions inherent in desiring to create an unrepresentable future that will only come to pass in ways we cannot imagine. 
So we create a proposition for a lesson, a lecture, a conference presentation, anything pedagogical, as artists working discursive-materially, attuned to and experiencing social, material and semiotic flows- perhaps goals, rubrics, lists, rationales and such are present here, further tracings. We have paper (once trees) that we will work on and that will work on us, butchers' paper that reminds us of the pedagogies of the slaughterhouse (Pedersen, 2013), immigrant paper that has come on a ship from London as packing material, yellowed by window sun, we have foil, tracing paper, plastic that reminds us of the beautiful artwork for the conference, string, tape, air, muscles. We think not of the affordances and constraints of this matter, but of how we are changing each other, human and inhuman, as we intra-act.

We also have ideas from theory and the conference. Here we have more recycled paper, print outs from medical journals with photographs of body parts, a further resource, on which we spend some time writing and drawing what we are thinking about, struggling with and intrigued by, as a beginning that is a middle. Then we will share these ideas.

We will work with anything at hand to form our proposition, and move around to engage with each other's work, to add, subtract, change, question, to further disrupt and complicate. There are no rules- you could also sit on the floor and read, or go outside to walk and think. You can feel what Jane Bennett describes as 'the thrust called intentionality' (2010, p. 32) now, but as she says, this does not define outcomes any more than the pebble in the pond. What emerge now as instructions have a fractal, rather than linear causality, or an emergent causality. 


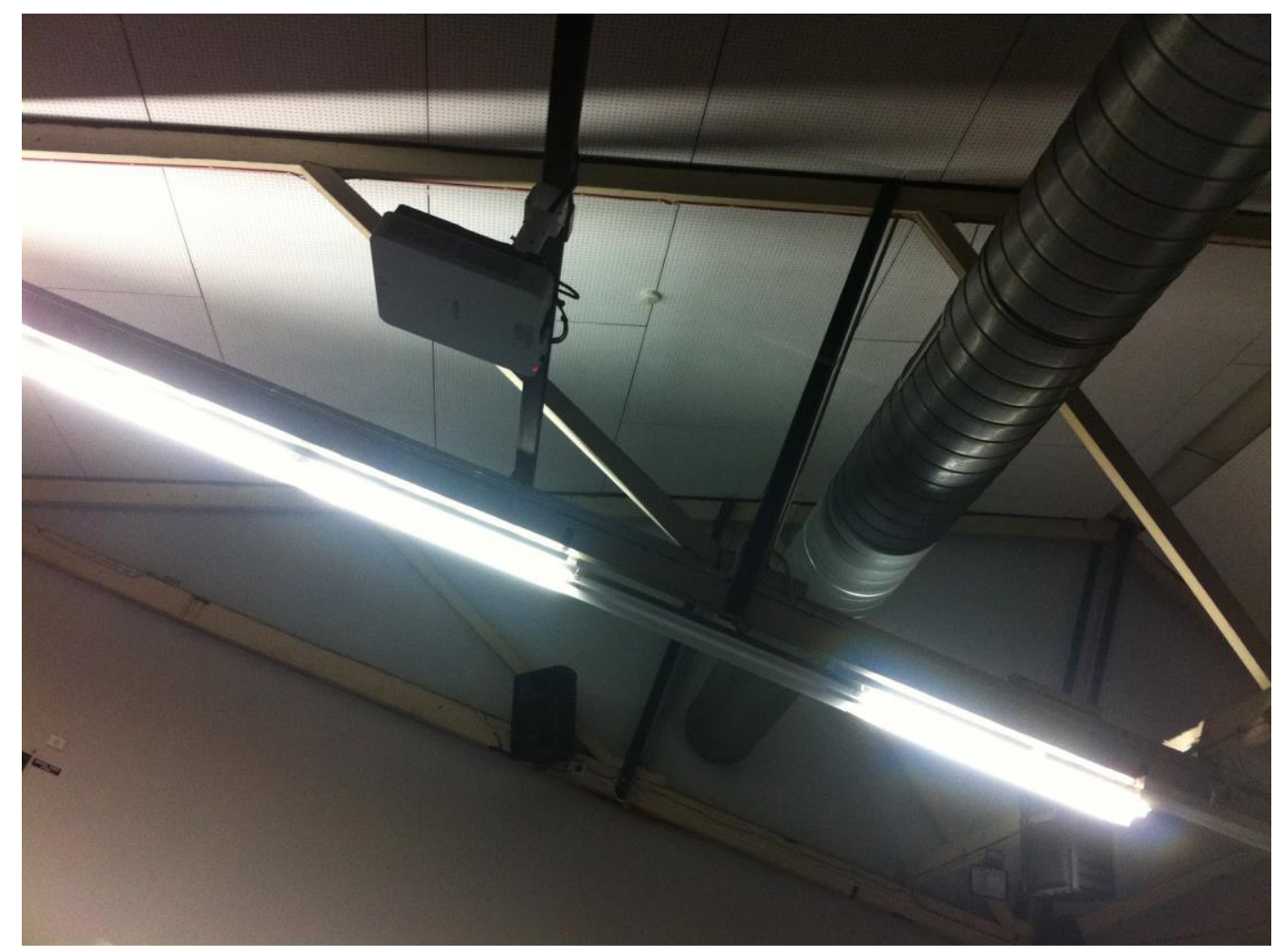

Figure 4: Victorian College of the Arts Art Auditorium ceiling

What happens? What emerges? How do we know? Walls, metal foil shards thinner than skin, fluorescent tubes, scattered paper fragments of theory on the floor, lenses, pictures of patients, bodies, paper, neon, paint, cables, scissors, carpet, gesture, vector, voice combine. What happens? What happened? What is happening? We move and intra-act, sharing the ideas that emerge both in the art auditorium space, as our physical assemblage, and also later in our online collaborative writing about transversal curricula.

\section{Part II Transversal curricula}

In this section, we compose, using text and photography, the curricular forms and practices we find ourselves wrestling with as responses to conference questions about how transversal practices work, how we might conceptualise them, and what approaches they call for in curriculum design. Material, geospatial and political curricula combine, 
entwine, entangle and mangle. Which matter makes itself felt, as we plan and un-plan together, talk, cut, stick and type? Each of these subsections and images forms a tangential cut (Barad, 2007) in the paper, a hole cut in the 'curriculum as plan' (Pinar, 2011, p. 1) and a cut in the tight fabric that forms our essentialised, ever compliant teacher identities in neoliberalism.

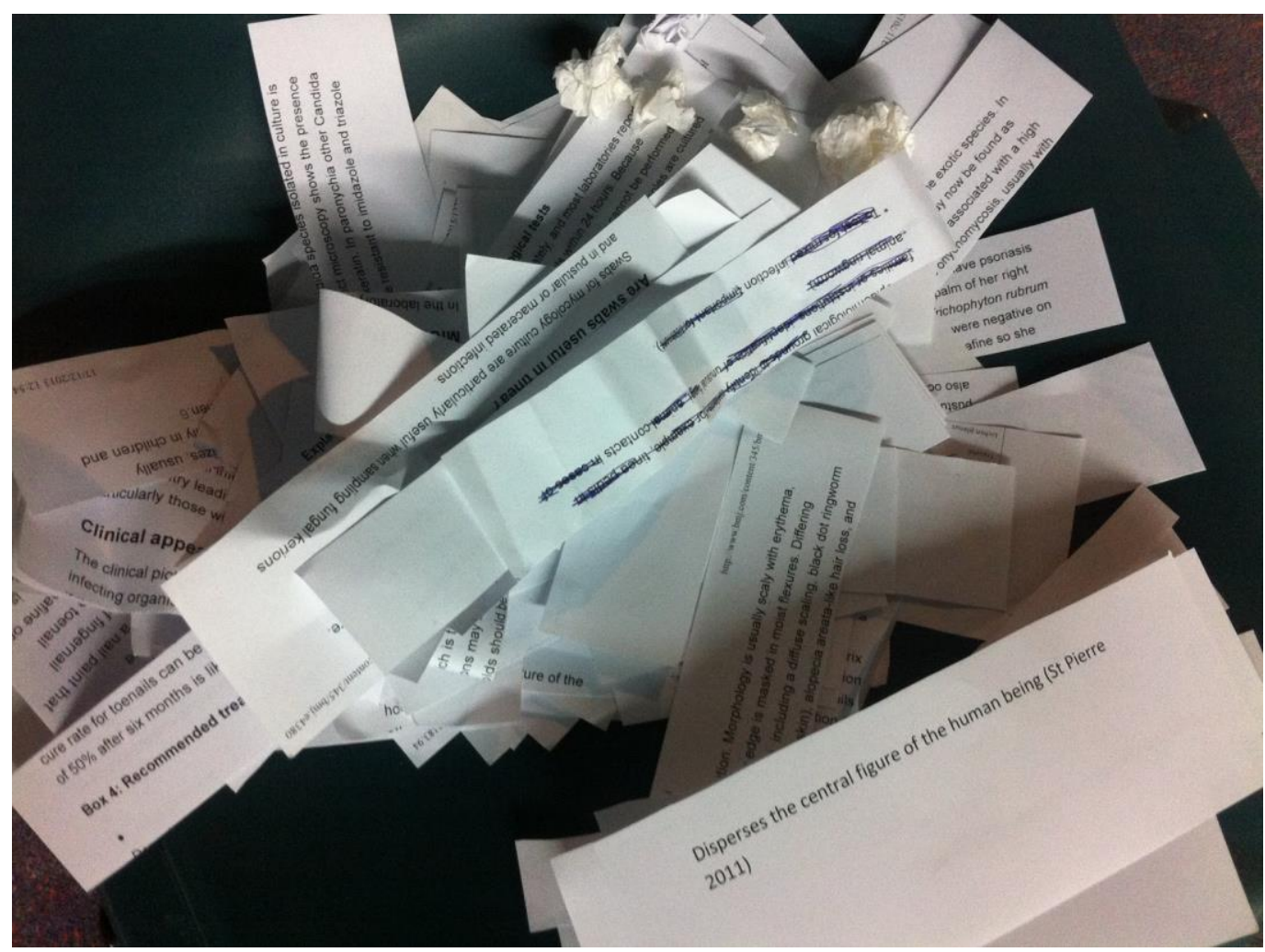

Figure 5: Workshop theory fragments used in assemblage

\section{A curriculum of collaborative writing}

We seek a curriculum of collaborative writing - a production, a mattering of written text to be shared with colleagues in two days' time. A temporal wave washes us in bodily affect. Dropping to the ground a big booted woman's body -so serious and restrained, crawls catlike. She seeks the familiar discursive that draws and blends the past, and future into the now-moment. She looks to the words in strewn quotations and there she becomes carpet, engulfed in the sinewy scratchiness. The blue wool pile that stretches before her. 
Four quotations shoot affect through this assemblage. These quotations are scraps, crisp paper fragments that deterritoralise now-thoughts with the possibilities of potential points of departure. They maintain the mobility of concepts (de Freitas \& Sinclair, 2013). University colleagues are summoned into the room, their bodies, ghosts alongside the new bodies present: 'Views representations as "condensations or traces of multiple practices of engagement" (Barad, 2007, p. 53)'. We hear plans, cohesions, separations in the space as bodies entwine and articulate materials that drape, point and frame new temporal spatial directions and connections for curricula projects. Sculptured in string that connect our bodies we talk of a curricula of cuts.

The yellow scissors appear disingenuous in their passivity. Terrible cyborgs, their past -future threats are evocative in the present. These agential objects evoke fear in their painful pasts and the affective threat-potential of future. Fear in the dress cuts of bound artists, fear inscribed in the bodies of teachers who prohibit their small charges access to the fearful power of cutting; the terror-grief of a mother who feels the cuts of surgery on her baby's body. She recognises that bodies 'glow' (MacLure, 2013, p. 661). In silence, we contemplate the blood curriculum of teen corporality -the multiplicitous cuts -an affect-anguish. She thinks of her daughter's body in the grips of the psy-machine. The pinging of the elastic band on her small wrist - positioned pathologised addict. She proposes what comes after governmentality (Lather, 2013).

It is a collision of material and discursive worlds to write these stories- so rich, painful and vital, into the folds of the academy, where colonising influences commodify blood, life and pain into publishable words. In it is (t)here in the control society with its 'spirit of gas' that an artifice of career construction is premised on academic hierarchies of visibility, invisibility and ghost worlds in between (Deleuze, 1992, p. 4). Yet this is where real blood flows and bodily connections become rhizomatic. We see blood 
curriculum in these arteries of the academy. There is no multifaceted conception of 'blood curriculum' in university databases. The inter-connections of cutting and curriculum yield articles on the reduction of legislated curriculum content (Hirsh, 2012; Wattenberg, 2014) and the conception of 'cross-cutting' as discipline integration (Bearet al., 2013; Splan, Porr, Broyles, 2011). Yet blood is an affective flow that touches our lives and spills from the academy.

\section{A curriculum of cuts}

Do you remember?

This is where we intersected, just for the briefest of time... it was at the point of our cutting together.

We were making and cutting and talking and thinking. A coming together and then off we went again into different trajectories, transversal crossings enacted in a collectivity of corporeality and incorporeality. The materiality of bodies and string made to stutter through the immateriality of our ghostly assemblages. A meshwork (Ingold, 2010, p. 11).

You were all covered in string and tangled up with materials and the string was around your neck even - you were embedded in this becoming/curriculum/materialising around and about you. Swaying and moving, bodies ebbing and flowing.

We talked about Yoko Ono's Cut piece which she performed at least six times at various locations. In it she as artist:

sat kneeling on the concert hall stage, wearing her best suit of clothing, with a pair of scissors placed on the floor in front of her. Members of the audience were invited to approach the stage, one at a time, and cut a bit of her clothes off-which they were allowed to keep (Concannon, 2008, p. 81). 
We talked about how you made yourself vulnerable, like her, through your cutting and shaping. And then you spoke about those operations. I thought about the agency of cutting and the power that children feel as they cut that first piece of paper... and how cutting is a journey into power... a way to a curriculum of possible changes that diffract the making hand... and how a curriculum of cutting stretches across our collective becoming. Cutting talks back to us through the power of our cut, the sensation that connects us. Where does the cut go next? Back to the umbilical. Eternal return: 'That which does not return, and does not exist, is nothing' (Young, 2013, p. 105, emphasis in original).

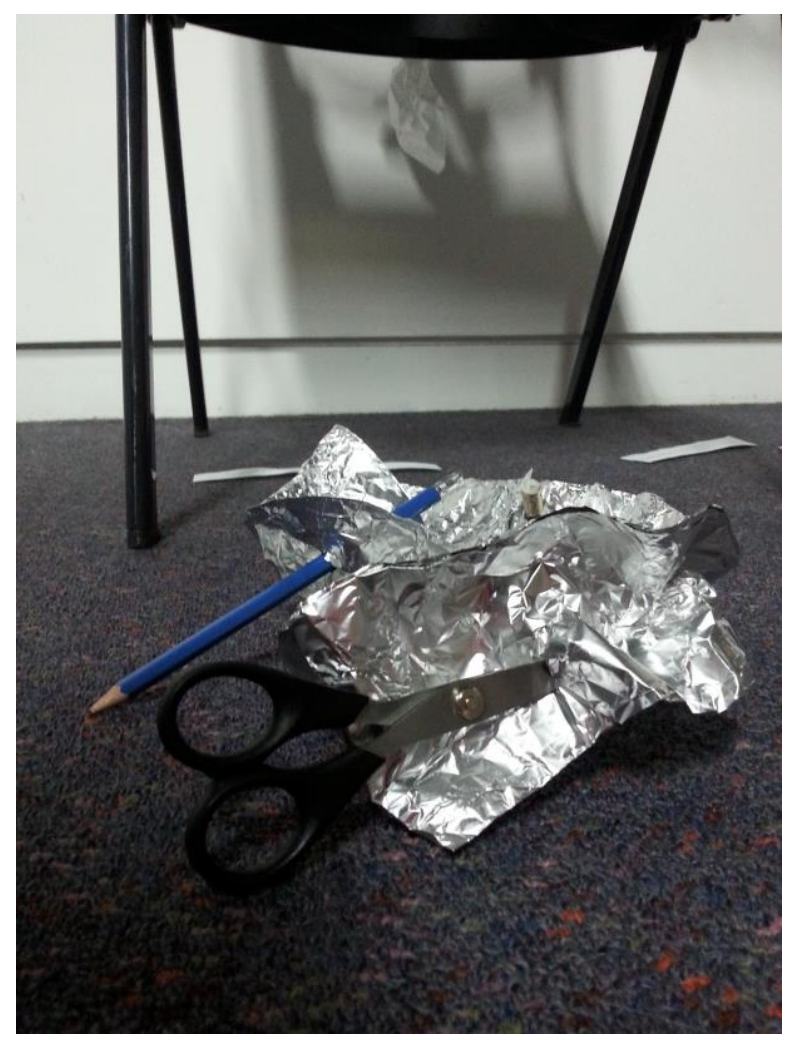

Figure 6: Foil and pencil workshop assemblage

\section{The dark curriculum}

Darkness lies within each drop of experience, each actual occasion in which an entity feels the world (Whitehead, 1978). Darkness also lies between occasions, between selves, in the chaosmic gap between one experience and the next. The 'specious present' slips 
from our grasp at each passing moment, as we stake our lives on 'speculative investments' in the unknown (James, 1996). We are caught in the shadowlands between the 'always already' and the 'not yet'; a discontinuous series of lived relations which are continuously smoothed over by after-thoughts, causal schematics and automatic interpretations. Can we think curriculum outside of thought? To operate in the darkness is to feel the world as it is for others than ourselves. Not ourselves, but together nonetheless; already a crowd (Deleuze \& Guattari, 1987). All together outside of thought. Just look at the moon. We know nothing about it. In looking at it, we increase it by one (Whitehead, 1978). This is the dark curriculum.

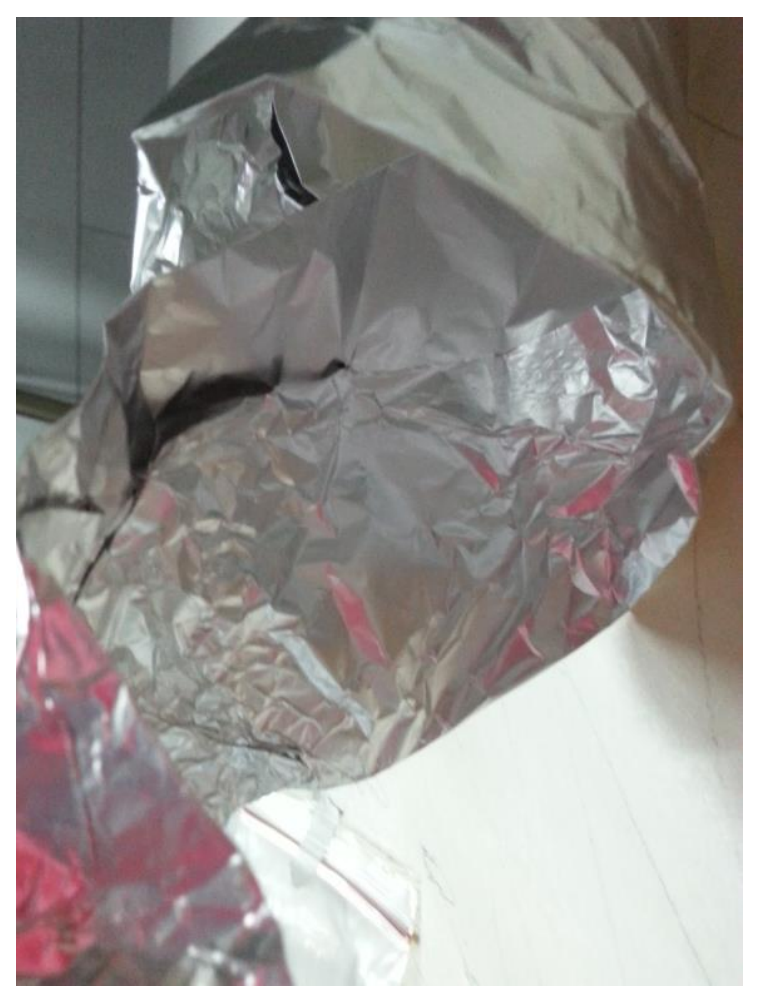

Figure 7: Foil detail of assemblage

\section{A mobile singularity}

There is text that can be read like braille on the surface of a moon, the bark of a tree, the wall of a classroom. It requires a curriculum that operates in $(n+1)$ dimensions, where invisible hands cut and stitch and stretch the skein of spacetimematter (Barad, 2007). 
Gravity pulls at the reticulated meshwork as the surface changes the coefficient of its viscosity, stretched to the limit but still holding its form. The lines of the meshwork cross but never touch, and in between each crossing there is a bubble that gets trapped in the web. The bubble expands and contracts with the brea(d)th of experience. Inside the bubble is darkness.

After the experience passes, the net snaps back to its holding pattern. The pattern can still be felt in the tensile suppleness of the material, the texture of the weave, the way it stretches then snaps back into shape. The next experience inherits the pattern, inhales the ghostly, dark materials of the past, and adds itself to the event. The Venetians call it ‘retticello', which means 'glass with a small network'. In 1919 Marcel Duchamp captures 50 CC's of Paris air in a sealed glass ampoule. He calls it 'Air de Paris'. It is an ecology of experience, a mobile singularity (Manning \& Massumi, 2014).

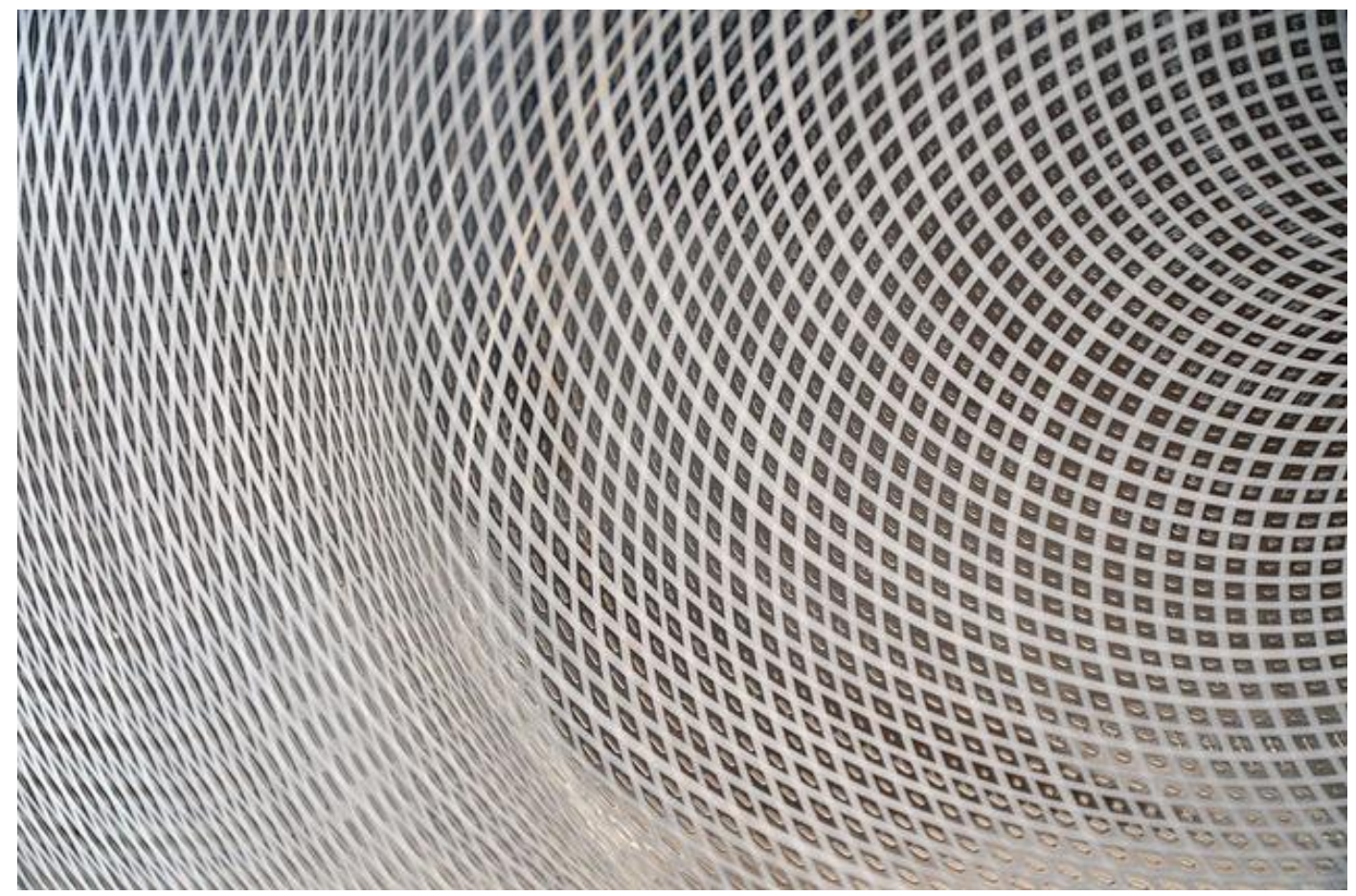

Figure 8: Parade plate, Venice, end of the 16th century or 17th century. Reticello filigree ( filigrana a reticello ) : grid or fishnet effect, with a tiny bubble in the middle of each stitch. Glass Museum in Murano. Used under Creative Commons CC0 1.0 Universal Public Domain Dedication. 


\section{A roll of the dice}

Philosophy is a roll of the conceptual dice, and this constitutes the pedagogy of the concept which cannot be determined in advance (Deleuze \& Guattari, 1994). We can never know in advance what someone will learn, or think, or do in response to the concept. 'The same pedagogical status of the concept can be found everywhere... the concept is the contour, the configuration, the constellation of an event to come' (p. 28). A pedagogy is an incorporeal sense event actualised through the bodily experience of teaching and learning. Pedagogies move like storms over the landscape, precipitating the experiences of teachers and learners, then moving on or drying out, increasing or decreasing in intensity. How many drops of rain will have fallen? Where will pools of water have formed? Which rivulets will have flowed into one another? Even after the storm it is hard to tell.

\section{Precipitation}

What curriculum lacks in prescience and predetermination, it can make up for in the immediacy of actualisation. The roll of the pedagogical dice makes the decision immediate. The passage of the experience comes to a terminus, a certain satisfaction of the event which precipitates the learning subject (Shaviro, 2009). The pedagogical stakes fall as they may. The storm comes and goes. The teacher|learner may or may not have emerged at all, or they may have emerged at the same time, or in succession, or one may have switched places with the other, an 'I' for an 'I'. In 1977 Walter de Maria arranged a field of steel rods in the desert to attract lightning storms. Sometimes the lightning strikes here, then here, then here. It did not strike here. No one can predict which rod will be struck, but the strikes are always immediate. Lightning travelling at the speed of thought. 


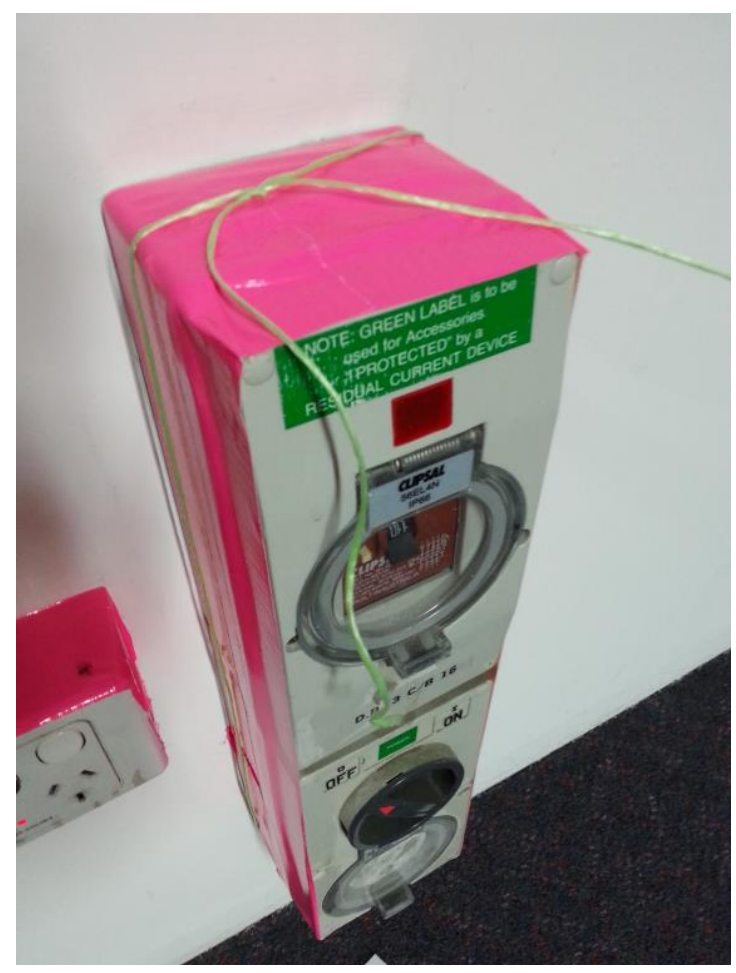

Figure 9: Tape, string, plug workshop assemblage detail

\section{A curriculum of storms}

The storm comes and goes.

There is a biological understanding residing somewhere in me on a cellular level that embodies the concept that a text can exist 'on new materialism simultaneously with its fleshing out of the new materialist ambition' (Dolphijn \& van der Tuin, 2012, p. 13). We are embodying this simultaneous concept repeatedly. I was pregnant with a foetus, and then culture dictated she became a baby at some point - and yet she was simultaneously being fleshed out for a further 17 weeks before she was asphyxiated by my ruptured placenta. What is concerning is that because her death occurred prior to her birth, some of us can no longer cope with the simultaneous. Her parents are all that are left to recognise her life-force ever had any sense of materiality. Interestingly, those fearing still-birth in society respond by focusing only on the fleshing out - and the tragedy of that interruption. 
Later, we were harshly reminded that the simultaneous is possible with the premature birth of her 25 week old tiny, fierce sister. I am crafting stories drawn from experience. Norman Denzin, in Interpretive Autoethnographies cautions that 'experience has no existence apart from the storied acts of performative I' (2014, p. 2). My own performative ' $\mathrm{I}$ ' is capsized by broken narratives of dead babes and ruptured bodies of premature infants, and infiltrated by a hopeful existentialism entangling a new metaphysics with metaphysics of presence (Denzin, 2014, p. 2). Ruptured by lightening, emerging as thought, landed.

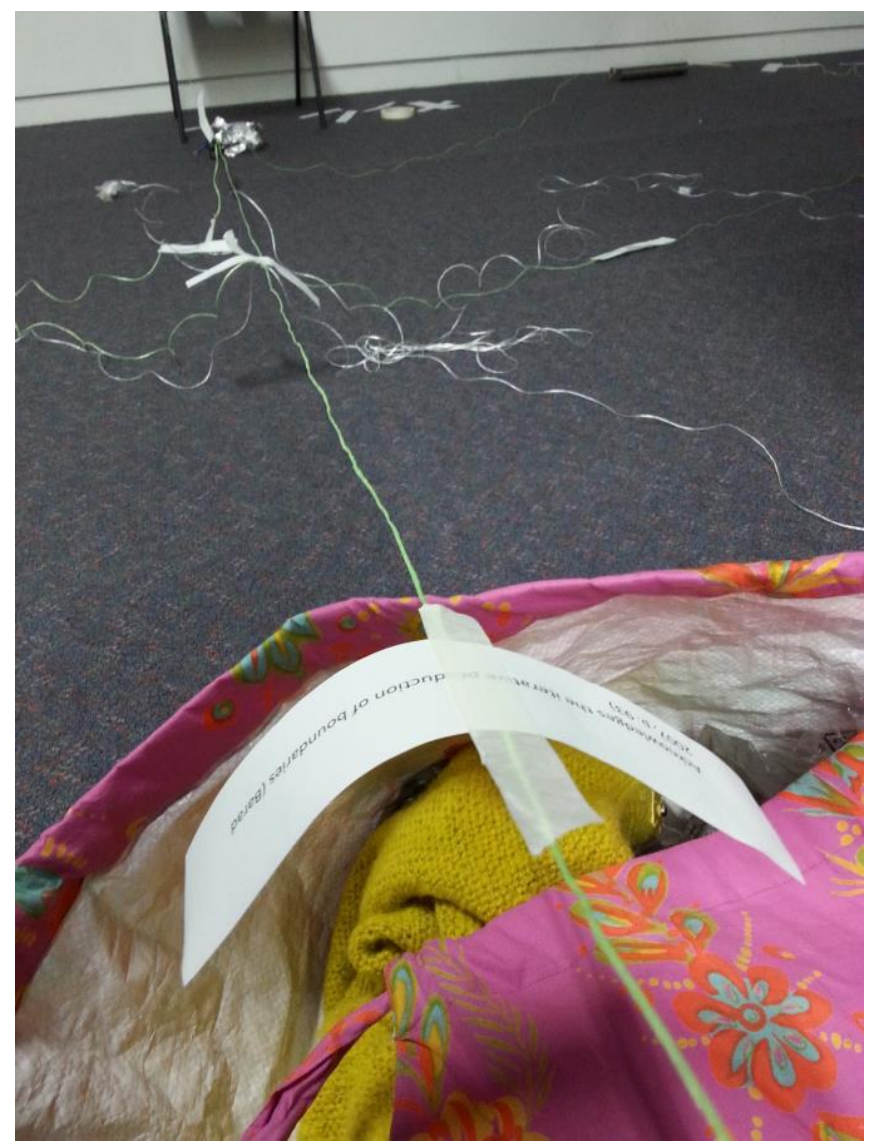

Figure 10: Presenter's bag, string, theory fragment assemblage detail

\section{Landing the Site}

de Maria's lightning field operates as what Arakawa and Gins (2002) call a 'landing site'. A landing site provides the architecture for a pedagogical event which both proceeds and 
precedes (exceeds) its immediation. 'The site lands itself for the body as much as the body lands the site'(Manning \& Massumi,2014, p. 24). A landing site is apportioned into a series of occasions (or shares) of experience through 'architectings of mobility' (p. 28). As for Whitehead, there is no simple location, only multiplicities, events, occasions, feelings, experiences, encounters (1978). The landing site exists before the encounter, and it continues to exist as long as the encounter is sustained (regardless of variations in scale and proximity). The landing site is the architecture for a relational encounter, like the parent-child, teacher-learner, artist-viewer, writer-reader, rock-water, or lightningrod. The landing site is 'preoperative', in the way that participation precedes cognition (Massumi, 2011), and prehension precedes operation (Manning \& Massumi, 2014). The landing site is designed for the lived abstraction of qualitative-relational experience (Massumi, 2011). The landing site is what we call the learning environment; this is the space of the conference workshop.

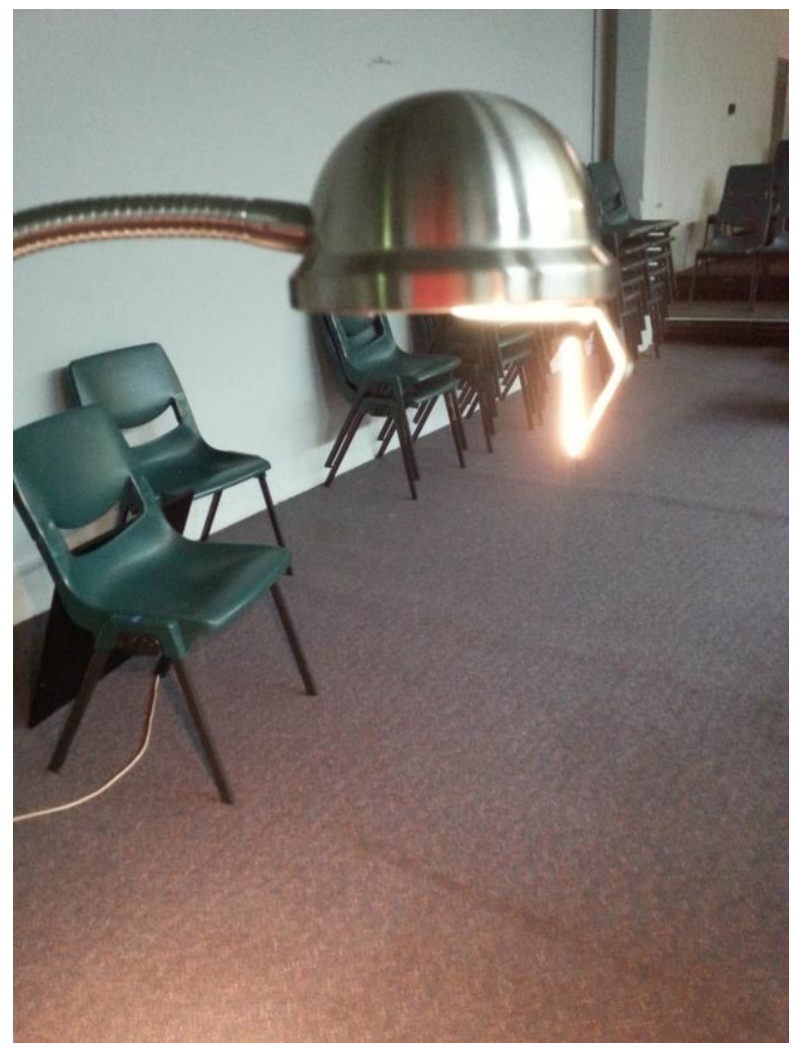

Figure 11: Art Auditorium light 


\section{Entering the Room}

We are already collaborating even before we enter the auditorium. In entering the room we will already have collaborated. The room is a landing site for a pedagogical event which is immanent (virtual) to our collaboration. After we leave the room we are still 'there', as long as we keep thinking together|apart as a relational encounter. We are 'there' and 'here' at the same time. When I sit down to work on this collaboration I go 'there', to the room, while remaining 'here', in my house. The landing site is multiple, like the experience of learning. The experience is shared out, apportioned each to his and her occasion of becoming (Manning, 2015). The landing site provokes an ethics of collaboration which cannot be separated from an (ecological) aesthetics which ontologically precedes it: 'we' don't exist prior to the collaboration, yet paradoxically, the collaboration doesn't exist before 'us'. This is the paradox of aesthetic causality, because each occasion is determined by how different things mutually affect (and have affected) one another (Whitehead, 1978). All that is given in advance of the occasion is the pure potential to land and be landed together, by a site which is both here and there, before and after.

\section{A curriculum of asynchronous poetry}

Does the poet feel the paradox of aesthetic causality? The creative and aesthetic potential of the theatre lies within the existential and ontological experience of being in the world. For the poet, his/her/their being in the world comes with creating patterns of words that live beyond earthly capabilities.

I see traces of poetry merging over the living - the distanced - the documented collaboration. The performative elements entwined within time/space - the script loose in its tangible state. The theatre director applauding, observing the elongated landing of 
creating art that lives beyond one's being. I am drawn to creating art that reminds me boldly that I exist -

and in this moment, I exist right now. And not any more. In New Zealand watching the sunrise as my fellow collaborators sleep after an evening of cursor-y discovery in a shared space, about a shared space discovery.

\section{Designing for transitional space}

The landing site is a holding environment for what D.W Winnicott (1987) calls 'transitional space'. A transitional space is a spatio-temporal hinge or opening that puts inner and outer realities into relation through playful inquiry and ontological experimentation. As Ellsworth (2005, p. 60) explains:

Winnicott saw [transitional space] as a relation of an unknowable (to itself as well as to others) mind/brain and body 'interior' to an unknowable and radically other 'exterior', and this transit across the space of difference between inside and outside is transitional because encounters with the "not me' that one find there and the actions that we take in response to such encounters change both the inside of the self and the outside of the social environment.

A landing site opens onto any number of transitional spaces, allowing for disjunctive temporalities to operate across an open series of distributed locations. Transitional space is a potential space, a phase space of possibility conditions which opens up in the learning environment. For Winnicott, these transitional spaces are always potential because 'nothing makes them inherently or inevitably transitional' (Ellsworth, 2005, p. 60). While an artist's or a teacher's design may hold within it the possibilities 
for transitional spaces to emerge, it is only through imaginative, immersive and playful engagement that these spaces are materialised. Transitional space can be designed for, but it cannot be designed.

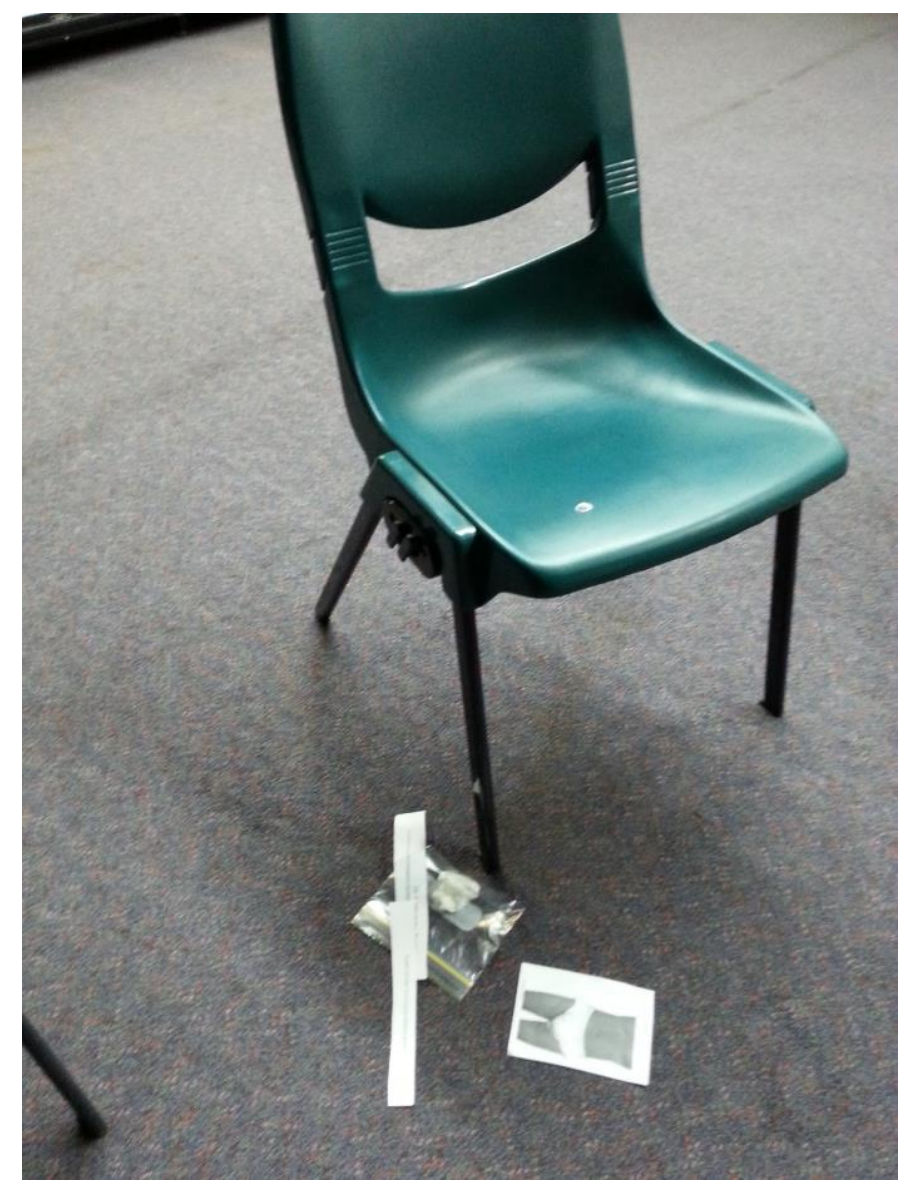

Figure 12: Chair, theory fragment, image assemblage

\section{A speculative curriculum of new materials}

Transitional space puts inner and outer, known and unknown, into material relation. This involves an emergent curriculum that is speculative and materialist at the same time. This is better described as a speculative curriculum of new materials, rather than a new materialist curriculum. We need only to glance over the millennia of Indigenous thought to realise that there is nothing new about materialist and relational ontologies. What is fundamentally new are the actual materials of everyday life, the rapid proliferation of bio-, nano- and information technologies along with the looming disasters of climate 
change, species extinction and resource depletion. Such accelerating rates of material change require a curriculum that operates speculatively across multiple temporalities and dimensions.

The invention of new transversal practices, techniques and technicities is also required (Manning, 2016). Textual crafting, graphic crafting, choreographies, carpentries, montages and métissage of images and ideas, knitting string over bodies in spaces, words, journals of journals, quilting memories. Sameshima says 'learning becomes the act of knitting experiences together, viewing the various degrees of separation and using the experiences themselves as discourse' (2008, p. 49). Each serendipitous moment, our pedagogies of surprise - our dark curricula, our speculative curricula, crafted by the anonymous hands that give rise to the performative curriculum-to-come. As the science fiction author Neal Stephenson writes:

We are tied in to everything here- plugged into the whole universe of information. Really, it's a virtual theatre. Instead of being hard-wired, the stage, the sets, cast and script are all soft- they can be reconfigured simply by shifting bits about.... The changes are dynamic and take place in real time. The show reconfigures itself dynamically depending on what happens moment to moment- and mind you, not just what happens here, but what is happening in the world at large' (1996, p. 387). 


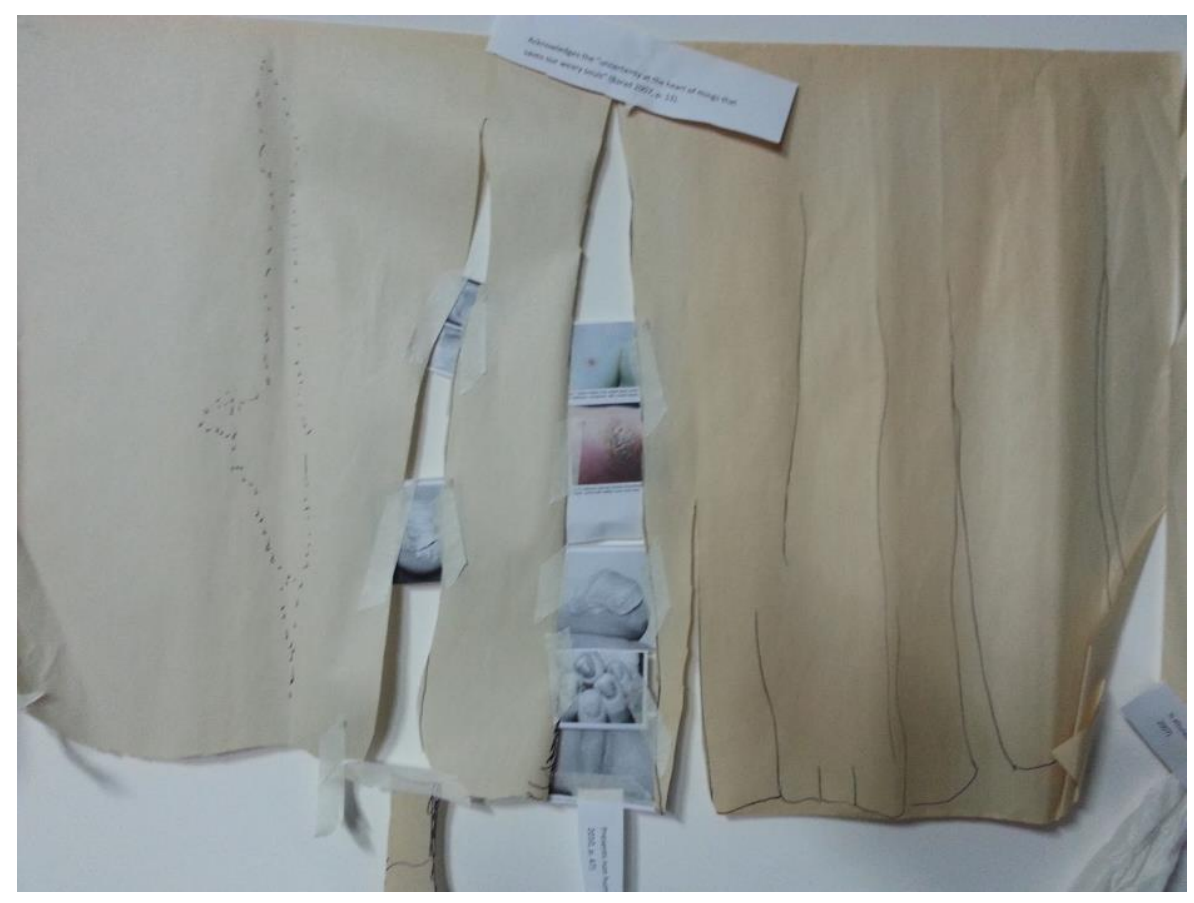

Figure 13: Paper, image, pen, theory fragment assemblage detail

\section{Part III: Intentionality and the invisible hand}

In this final section, we re-assemble the human who submitted the abstract for the workshop and join her in the auditorium as she enters into the work of preparing for the conference session, work that begins before the conference, and continues afterwards, as we make our strategic cuts in the online document and sketch forming curricula. This is diffraction, rather than reflection (Barad, 2003), incorporating subsequent words and ideas from participants, showing how intentionality might briefly coalesce, then become what we have never imagined, what we can never pin down. This paper itself is multiple and recursive, telling no single, linear story; we collectively write this 'I'. 


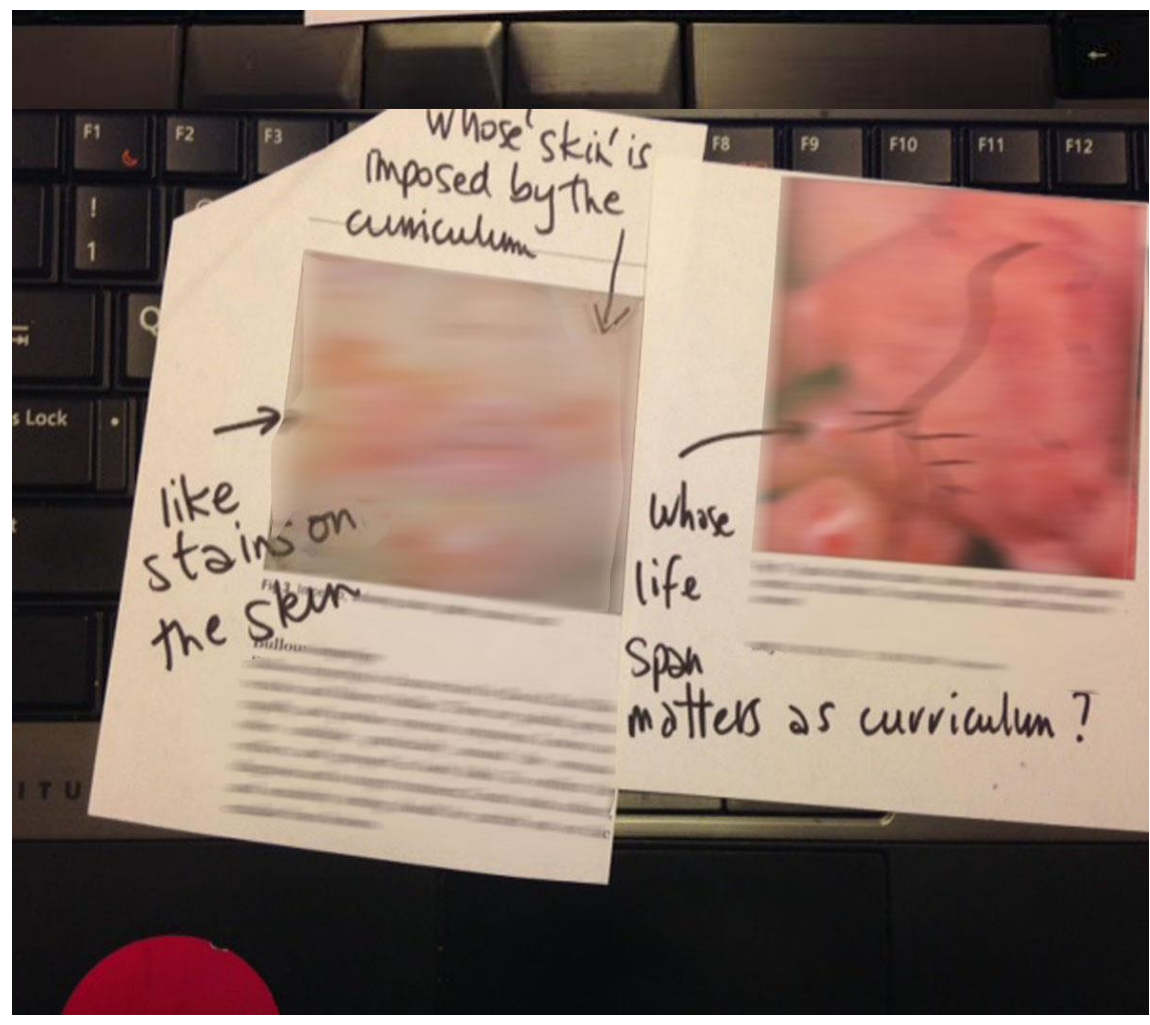

Figure 14: Workshop image fragments in a new assemblage, with the author's keyboard at home

Panic, the projector won't work, the password fails, the mask falls from the cardboard box mangle my child son has made for fun. The room and I need to get ready. Chair, lamp, envelope. I pin up paper, scatter quotation theory strips around the perimeters. Workshop participants will be arriving any moment and I must be gone. The huge room is empty of people and part full of light and sound, fluorescent glare and plumbing gurgles in the walls. One side of the room, though, is dark. No one will go there. What will happen in a conference workshop without a presenter? I want to see what will happen when you cut holes in the conference, cut out the presenter, at least at the start. I have envisaged pedagogies of surprise, reversal, decentring, dehumanising the teacher, of spontaneity, flattening, affect, unease. Is this a joke? Will anyone walk out? What will happen, as together we enter into the co-design of the event of learning in the making? 


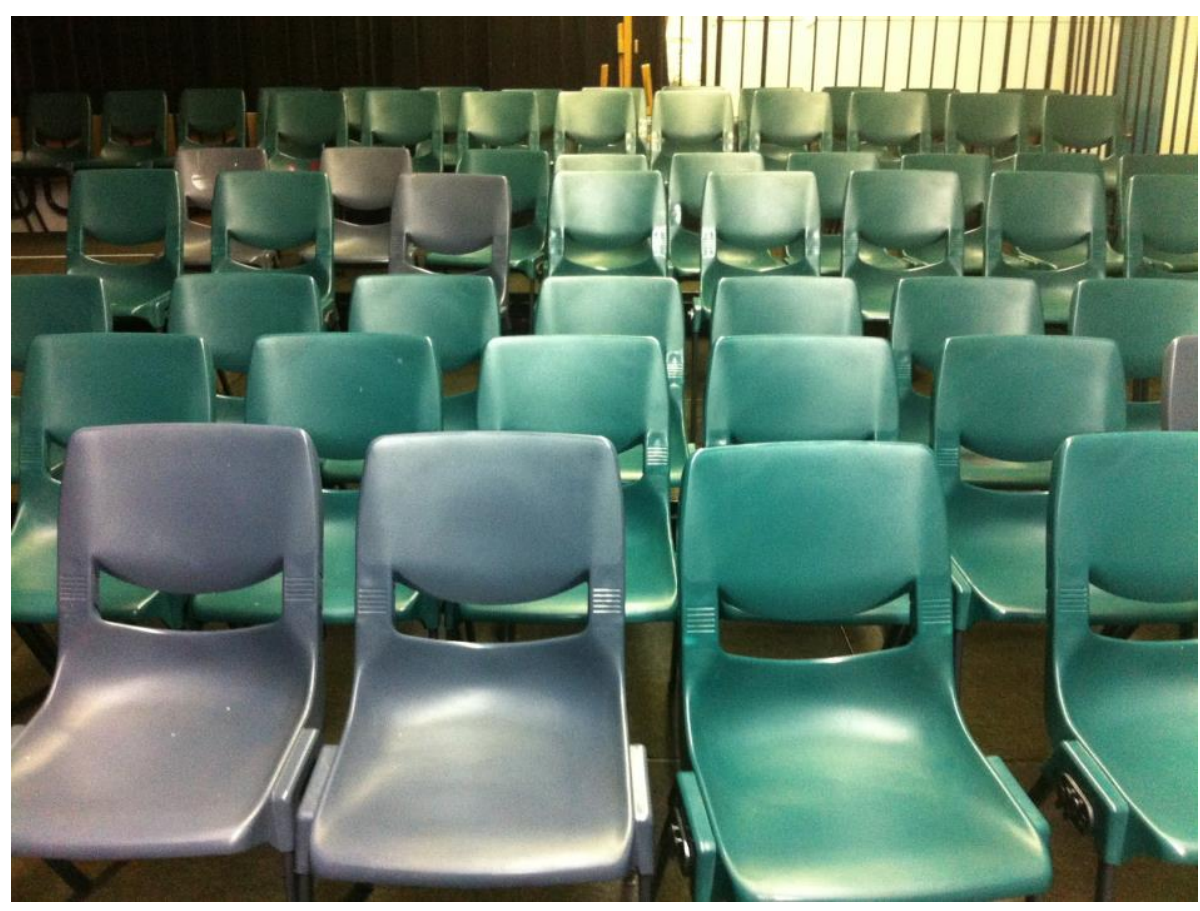

Figure 15: Art Auditorium seating

Stand outside the side door- know the workshop is starting without me. The conference coordinator waits outside the main door to limit numbers. I enter like a participant and sit with the others, who have already opened the envelope and are reading out the statement, negotiating. When will 'I' emerge? What if 'I' don't emerge? We mingle and shake hands, share our names and some people remember the avatar-name-me who appears in the program. Do I want to give this over? Do I want to give up my momentum? My agenda? My intentionality? Participants start looking at me. I know what I envisage: that everyone will work on an individual project, neatly beside each other at the walls. Plan a lesson with the matter I have brought along, the string, plastic, pencils, tape.

Make matter matter in the classroom and on the walls, put our discussions and these found objects to work in an artful way to solve the problem of curriculum post humanism, of the invisible human hand present in the lesson plan, that massages us all towards being better humans, less savage or un-human. This is more than student-centred learning. This might be carpet-centred learning. It might be anything. I imagine us 
walking around, looking at each assemblage, on a guided tour ten minutes before the end, (I don't see this yet but) inevitably performing the outcomes of humanist education. Yet when we diffract, we produce something unexpected.

The materials are available, spread out on the floor, inviting us to touch shiny foil and louche string. We talk. We- human bodies, pencil bodies, float in the space, where, as Erin Manning says later in her keynote address, 'given-ness and potentiality overlap' (2015). My expectations of rhythm, of sequencing, of introduction, development and conclusion, of evaluation and of control relax, briefly. We are tied up with string, linked up to walls and chairs where the string is taped and looped. Everything is connected. Invisible hands have woven it around our legs as we talk. The formal and informal spaces of the chair circle and wall gallery merge and break up, people are sitting on the floor, someone has string around her neck, chairs have string around their legs. The neat lesson plans, with their accompanying exegeses, do not emerge.

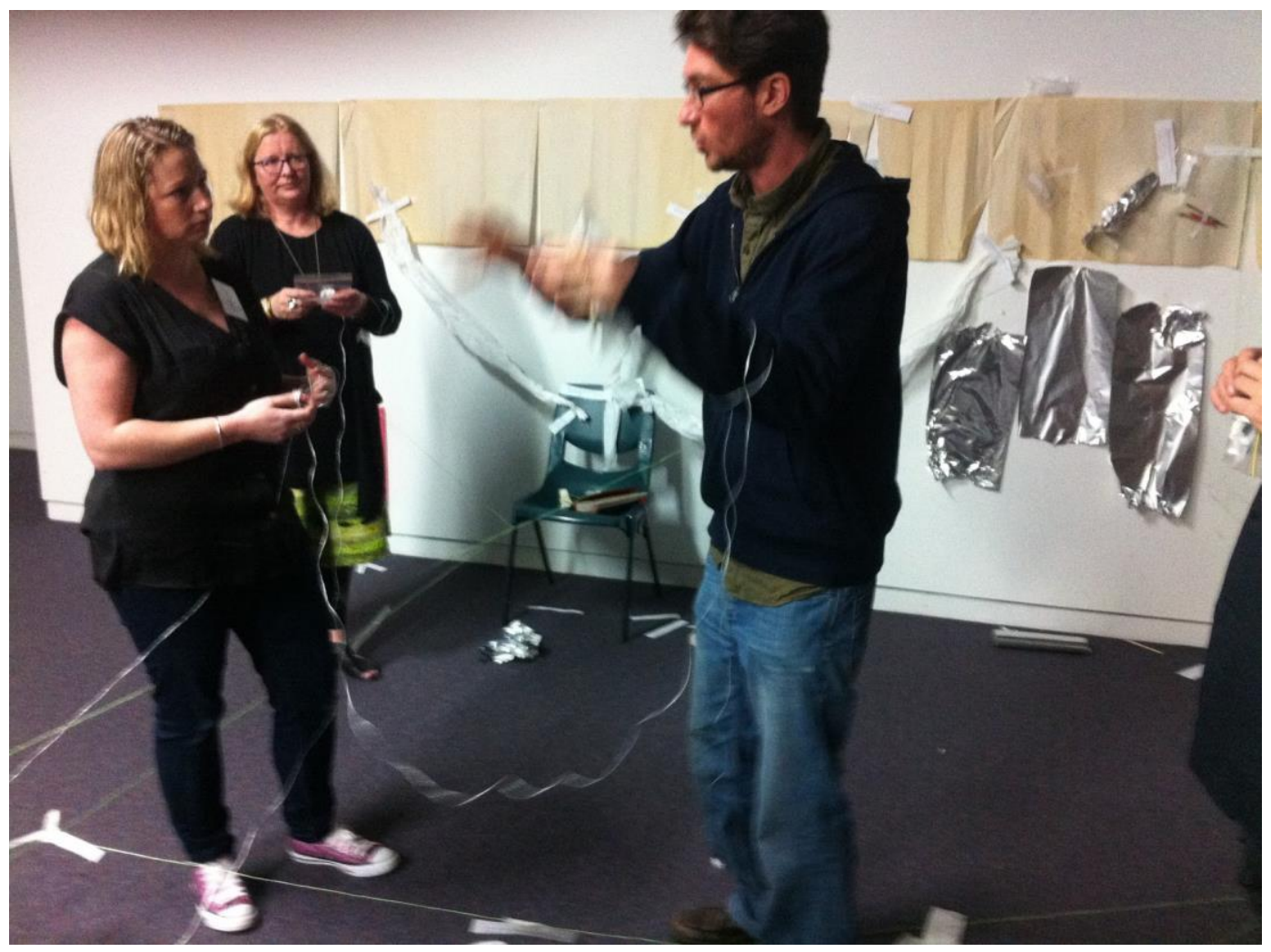

Figure 16: Authors and other bodies participating in workshop 
Bodies bend and reach, and stick quotes on the wall where other people have begunsomeone wants to link all the beginnings. Some have not even begun. Something in me starts up, 'I need', 'I need', and it's the old classroom voice that wants everyone on their own page, that is, my page. I want to move my arms, direct traffic, conduct a choir. I wonder if everyone is bored, dying to escape. ('Where is the handout?' I have been asked before at a conference. 'Why is there nothing to take away?' as if the presentation exists as a piece of paper.) Yet no one leaves. We are composing and being composed, playful, undisciplined, foraging for theory, having private conversations crouched on the floor, making marks here and there on the walls.

The materials I have brought with me come to life in this space, as do we. Someone admires the faded old butcher's paper, with its modulated sepia shades, that I regretted. It is something different here. Other objects recede. The mangle is no noveltysome of us are art teachers, and such objects are everyday. The room has dictated what happens- as I cannot log in to the computer, I cannot dominate via the enormous screen. A larger, playful work is happening, and moving with us inside it, string bound, breathing in and out as we approach and recede from the walls, approach and recede from each other. But what if people do not 'get out of this' what the program promised? What does that desire say, epistemologically?

Nobody wants to leave, though. We stay on and on past the time the ninety minute workshop should end. We are staying in a communal space we and the walls have made, that intra-action brought into being, which seems to have its own magnetic force. We have not done anything that I imagined, even in my attempt to not imagine much. We start to talk about continuing in another space, online, writing together for the conference journal volume. A room made a workshop. We will diffract that with writing in a new 
space, this writing, again forming something new, that is no mere representation, but a fierce new entity that will include, exclude, privilege and silence, through screen, pixels, software, the staccato fix of typing, breath and blood pumping, legs cramping. So many invisible hands tap-stabbing at the dilemma that we struggle to think or plan outside humanism.

Bodies begin to drift away. I cut the string, pull down the papers, pick up dirty fragments of theory from the floor, then stuff the mass into my bag. It won't go in. It is so much more than it was before, an unruly bulge of folded papers and tangled string. And this is not the half of it. As Manning says, 'Art is always in excess of what it leaves behind' (2015). How to assess, as if we must, this mess-mass? Did we transversally challenge the key binaries that thinking curriculum with new materialism exposes? Did we memorise summaries of key theories? Did we grasp a methodology, a neat template for future transversal conference sessions? There was no survey to check. We do not know what anyone 'took away' from the workshop, or more particularly, what anyone will make now, how anyone might emerge now.

This new writing is not in the form of answers to these questions, so that we might lasso some outcomes, but further intra-action, further forming of new connective tissue, such that perhaps we can stop thinking of invisible hands (so human) but invisible strings attached to machines and architecture and all kinds of bodies. This is also the string cut and recycled daily from the bulging conference bag, matter endlessly formed and forming. We refuse to be reduced (Lather, 2013, p. 645), in the afterward. What if this paper is an 'outcome' of the session, an outcome the curriculum planner did not envisage? Why should we end here, with a tight narrative conclusion? Would other conference papers dare to give this away, this final gasp of mastery? What about a paper that unravels 
at the end, into a long, twitching kite tail tangle of idea-twine fragments? A conclusion of questions. Of ideas we brought, bring, will bring, into being together, curricula of

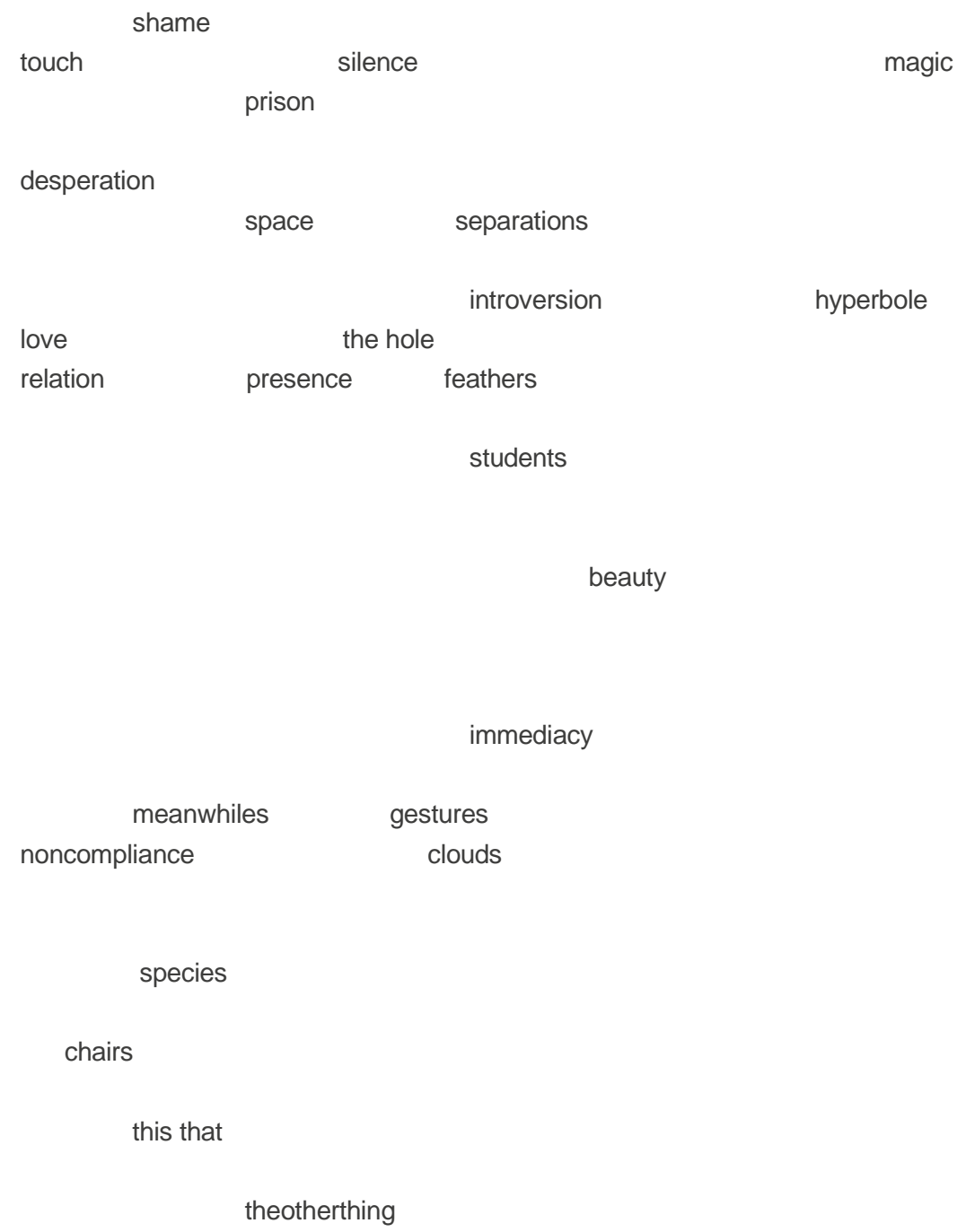




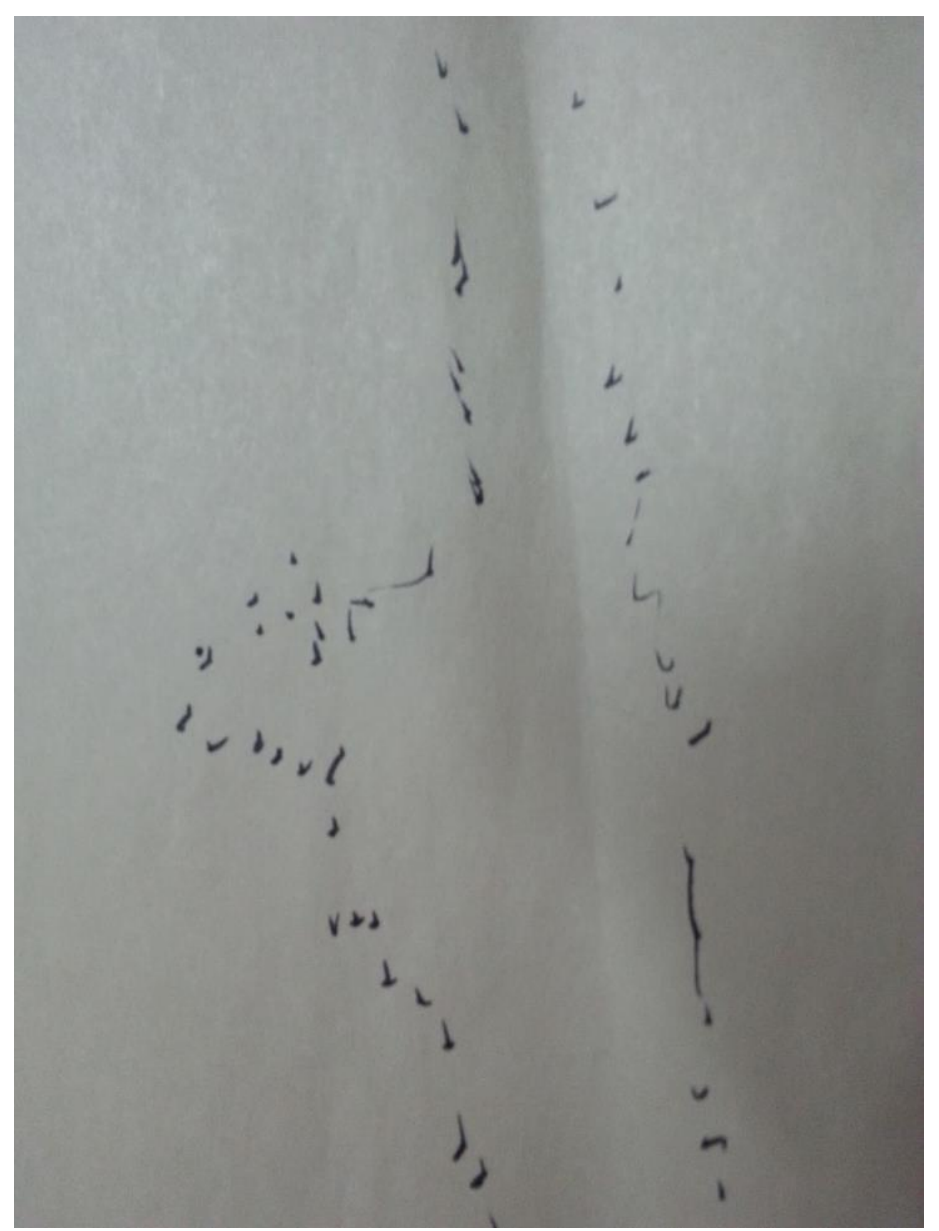

Figure 17: Workshop assemblage drawing detail

Acknowledgements: The authors would like to acknowledge the participation of Sarita Galvez and Andrew Landrigan in The Invisible Hand workshop. 


\section{References}

Arakawa, S., \& Gins, M. (2002). The architectural body. Birmingham AL: University of Alabama Press.

Barad, K. (2003). Posthumanist performativity: Toward an understanding of how matter comes to matter. Signs: Journal of Women in Culture and Society, 28(3), 801-831.

Barad, K. (2007). Meeting the universe halfway: Quantum physics and the entanglement of matter and meaning. Durham, NC: Duke University Press.

Bear A., Simpson, D., Brown,D., Bragg.D., \& Marcdante K. (2013). Faculty and students perceive common tenets associated with medical student curriculum reform. International Journal of Medical Education, 4, 186 - 192. doi: 10.5116/ijme.5221.ad07

Bennett, J. (2010). Vibrant matter: A political ecology of things. London: Duke University Press.

Coole, D., \& Frost, S. (2010). Introducing the New Materialisms. In D. Coole \& S. Frost (Eds.), New Materialisms: Ontology, Agency and Politics (pp. 1-43). London: Duke University Press.

Concannon, K. (2008). Yoko Ono's cut piece: from text to performance and back again. Performance and Art Sep (90). pp. 81-93.

Cutcher, L., Rousell, D., \& Cutter-Mackenzie, A. (2015). Findings, Windings and Entwinings: Cartographies of collaborative walking and encounter. The International Journal of Education Through Art, 11 (3), 449-458.

de Freitas, E., \& Sinclair, N. (2013). New Materialist ontologies in mathematics education: The body in/of mathematics. Education Studies in Mathematics, 83(3), 453-470.

Deleuze, G. (1992). Postscript on the societies of control. October, 59, 3-7.

Deleuze, G., \& Guattari, F. (1987). A thousand plateaus: Capitalism and schizophrenia. Minneapolis: University of Minnesota Press.

Deleuze, G., \& Guattari, F. (1994). What is philosophy? New York, NY: Columbia University Press.

Denzin, N. (2014). Interpretive Autoethnography (2nd ed.). Thousand Oaks, CA: SAGE.

Dolphijn, R., \& Tuin, Iris van der. (2012). New materialism : Interviews \& cartographies (New metaphysics). Ann Arbor: MI, Open Humanities Press. 
Ellsworth, E. (2005). Places of learning: Media, architecture, pedagogy. New York, NY: Routledge.

Gaztambide-Fernandez, R. (2015). Thinking beyond the human. Curriculum Inquiry, 45(3), 245-248.

Hirsh, L. (2012). Think globally, teach locally: NewSchool taps world's design talent for cutting-edge curriculum. San Diego Business Journal. 33(47), 1.

Ingold, T. (2010) Bringing things to life: creative entanglements in a world of materials, NCRM working paper, 06/10, pp. 1 - 14. Retrieved from http//eprints.ncrm.ac.uk/1306/1/0510_creative-entanglements.pdf.

James, W. (1996). Essays in radical empiricism. Lincoln, NB: University of Nebraska Press.

Lather, P. (2013). Methodology 21: What do we do in the afterward? International Journal of Qualitative Studies in Education, 26(6), 634-645.

MacLure, M. (2013). Researching without representation: Language and materiality in post qualitative methodology. International Journal of Qualitative Studies in Education, 26(6), 658-667.

Manning, E. (2015, September). Carrying the feeling. Paper presented at Transversal Practices: Matter, Ecology and Relationality, VI International Conference on New Materialisms, Melbourne, Australia.

Manning, E. (2016). Ten propositions for research-creation. In N. Colin \& S. Sachsenmaier (Eds.), Collaboration in performance practice: premises, workings and failures (pp. 133-141). New York, NY: Palgrave MacMillan.

Manning, E., \& Massumi, B. (2014). Thought in the act: Passages in the ecology of experience. Minneapolis, MN: University of Minnesota Press

Massumi, B. (2011). Semblance and event: Activist philosophy and the occurrent arts. Cambridge, MA: The MIT Press.

Mazzei, L. A. (2013). A voice without organs: Interviewing in post humanist research. International Journal of Qualitative Studies in Education, 26(6), 732-740.

McKnight, L. (2015). Open me when you feel it's necessary. Melbourne: Victorian College of the Arts.

Otterstad, A. M. and Waterhouse, A. L. (2015). 'Beyond regimes of signs: making art/istic portrayals of haptic moments/movements with child/ren/hood'. Discourse: Studies in the Cultural Politics of Education, 37(5), 739-753. 
Pedersen, H. (2013). Follow the Judas sheep: Materialising post-qualitative methodology in zooethnographic Space. International Journal of Qualitative Studies in Education, 26(6), 717-731.

Pinar, W. F. (2011). What is curriculum theory? New York: Routledge.

Rhoades, T., \& Brunner, C. (2010). Transversal Fields of Experience. Inflexions, 4, i-vii. Sameshima, P. (2008). AutoethnoGRAPHIC relationality through paradox/parallax and metaphor. In S. Springgay, R. Irwin, C. Leggo \& P. Gouzouasis (Eds.) Being with a/r/tography. Rotterdam: Sense, 45-56.

Shaviro, S. (2009). Without criteria: Kant, Whitehead, Deleuze, and Aesthetics. Cambridge, MA: The MIT Press.

Snaza, N. (2015). Toward a geneaology of educational humanism. In N. Snaza \& J. Weaver (Eds.), Posthumanism and educational research (pp. 17-42). New York: Routledge.

Splan, R., Porr, S., \& Broyles, T. (2011). Undergraduate research in agriculture: constructivism and the scholarship of discovery. Journal of Agricultural Education, 52(4), 56-64. Retrieved from http://go.galegroup.com.ezproxy.une.edu.au/ps/i.do?id=GALE\%7CA276808974 $\& \mathrm{v}=2.1 \& \mathrm{u}=\mathrm{dix} \operatorname{son} \& \mathrm{it}=\mathrm{r} \& \mathrm{p}=\mathrm{AONE} \& \mathrm{sw}=\mathrm{w} \& \mathrm{asid}=\mathrm{c} 3 \mathrm{f} 41 \mathrm{~b} 9 \mathrm{c} 12 \mathrm{ae} 3 \mathrm{~d} 593 \mathrm{c} 776 \mathrm{a} 19$ $70 \mathrm{a} 64 \mathrm{~b} 7$.

Stephenson, N. (1995). The diamond age, or a young lady's illustrated primer. London, England: Penguin Books.

van der Tuin, I., \& Dolphijn, R. (2010). The transversality of new materialism. Women: A Cultural Review, 21(2), 153-171.

Wattenberg, R. (2014). Content on the cutting-room floor: a brief history of the elementary curriculum. American Educator, 38(2), 22. Retrieved from http://www.aft.org/periodical/american-educator/summer-2014/content-cuttingroom-floor

Whitehead, A.N. (1978). Process and Reality. New York, NY: The Free Press.

Young, E.B. (2013). Eternal returns. In Young, E.B., Genosko, G. \& Watson, J. The Deleuze and Guattari Dictionary. London, UK: Bloomsbury. 
Figure 1: The Invisible Hand conference workshop assemblage detail

Figure 2: Walls ready for The Invisible Hand Workshop

Figure 3: Cardboard box mangle displayed at workshop, made by presenter's son

Figure 4: Victorian College of the Arts Art Auditorium ceiling

Figure 5: Workshop theory fragments used in assemblage

Figure 6: Foil and pencil workshop assemblage

Figure 7: Foil detail of assemblage

Figure 8: Parade plate, Venice, end of the 16th century or 17th century. Reticello filigree ( filigrana a reticello ) : grid or fishnet effect, with a tiny bubble in the middle of each stitch. Glass Museum in Murano. Used under Creative Commons CC0 1.0 Universal Public Domain Dedication.

Figure 9: Tape, string, plug workshop assemblage detail

Figure 10: Presenter's bag, string, theory fragment assemblage detail

Figure 11: Art Auditorium light

Figure 12: Chair, theory fragment, image assemblage

Figure 13: Paper, image, pen, theory fragment assemblage detail

Figure 14: Workshop image fragments in a new assemblage, with the author's keyboard at home

Figure 15: Art Auditorium seating

Figure 16: Authors and other bodies participating in workshop

Figure 17: Workshop assemblage drawing detail 